\title{
THE SPECIFICITY OF THE BORDET- WASSERMANN REACTION. PRELIMINARY NOTE ON AN IMPROVED METHOD
}

\author{
By G. M. RICHARDSON, D.Sc.
}

[From the Pathological Laboratory of the Ministry of Health.]

THE clinician's demand upon a serum test for syphilis is that it shall have the maximum sensitivity obtainable without loss of specificity. Specificity is thus a limiting factor in the growth of sensitivity. In the BordetWassermann complement-fixation reaction, specificity is controlled both by the proper adjustment of hæmolysis times to suit the balance of the hæmolytic system, and by the purity of the lipoidal extract used as antigen. In the past, much attention has been given to the former requirement (see, e.g., Kolmer, I928; Eagle, I937), but progress with the latter (see, e.g., Browning and McKenzie, I924; Eagle, I937) has been restricted by the chemical difficulties of isolating an immunologically pure lipoid. The present paper reports a study, pending suitable isolation of the lipoid, of the use that can be made of zone phenomena to distinguish between specific and nonspecific fixations.

The reactants in any antigen-antibody system may be combined in a certain ratio which is optimum for demonstration of the reaction, and combinations in other proportions may partially suppress the demonstration, giving zone inhibitions (Marrack, I938). If small amounts of antigenic impurity are present in the antigen, the effect of altering combining proportions so as to bring zone inhibitions into play can be used to distinguish between specific and non-specific reactions. This generally useful device can be applied to any antigen-antibody system which is liable to zone inhibition, not excluding systems with lipoidal antigens.

In this paper, the value of this guide to specificity has been tested in a suitable adaptation of the Harrison-Wyler (Wyler, I929) and Wyler (I932) methods of the WasserI66 


\section{THE BORDET-WASSERMANN REACTION}

mann reaction. As a result, the sensitivity of the latter method has been maintained, and linked with an important improvement in the detection of partial fixations (" doubtful reactions ") of diagnostic significance. The new method is thus especially useful in dealing with the weak serum reactions which occur with increasing frequency in present-day laboratory experience.

It was hoped to compare this method with others at a serum Conference convened for last September-October at Copenhagen, and to defer publication until after this Conference. International events have, however, prevented the Conference, and temporarily suspended further

- trials in this country. Though certain technical details are still under study, the value of the results so far obtained has seemed sufficient to justify a report at the present stage. The work so described refers only to sera, but preliminary tests made with spinal fluids suggest that the method may be equally useful with them.

Application of the method to techniques using spirochætal antigen (the Reiter strain of Treponema pallidum; Gaehtgens, I929; Beck, I939; Eagle and Hogan, I940) might seem, at first sight, to be especially useful. In series of several thousand tests, the spirochætal antigen has been found to give an increased number of fixations with both syphilitic and non-syphilitic sera, as compared with the lipoidal antigen (Gaehtgens; I932; Vogelsang, I940). Elimination of these non-specific fixations would therefore be important, but it seems that the concentration of spirochætal antigen required for complement fixation by this method is so high as to give little opportunity for inducing zone inhibitions by antigen excess.

\section{HISTORICAL SUMMARY}

Early methods of performing the Bordet-Wassermann reaction were designed to detect syphilis among a population which had not been brought under adequate control and treatment. As developed in this country, these methods were based on the use of fortified lipoidal emulsions (see Browning and McKenzie, McIntosh and Fildes, and Harrison; Medical Research Committee, I92I), and have had sufficient sensitivity to give stalwart service in the ensuing years. At present, however, the more common demand upon methods is to control the 
effectiveness of treatment or to detect the weaker reactions sometimes occurring with latent or congenital syphilis. Consequently, the finer degrees of sensitivity have become increasingly important, and in this respect the early Wassermann methods have been surpassed in laboratory trials by serum flocculation methods, which were shown to be very useful in expert hands (League of Nations Health Organisation, I929, I93I). The sensitivity of Wassermann methods revealed at these Conferences has, however, proved to be capable of improvement (Wyler, I932), and in more recent developments attention has been especially directed to the use of optimum combining proportions of serum and antigen (Eagle, I936 ; Boerner and Lukens, I937; Wadsworth et al., I938b).

These developments of technique may be illustrated by the methods depicted in condensed form in Table $I$. All these methods employ inactivated serum, pooled guinea-pig complement, and lipoidal heart extract (usually fortified with cholesterol to varying extents), and all but the methods of Kolmer, Griffith and Scott, and Ruediger use sheep cells sensitised with rabbit $v$. sheep amboceptor (Kolmer employs cells and amboceptor separately, Griffith and Scott, horse amboceptor, and Ruediger, human cells with suitable rabbit amboceptor). Most of the methods employ a certain degree of cool (room temperature) or cold (ice-box) fixation.

Table I shows that two ways of estimating the strength of a reaction are in use. The first depends on fixation of a standard complement dose by varying amounts of serum, and the second on fixation of varying complement doses by a constant serum amount. There seems to be no finality as to the relative merits of either. It is noteworthy, however, that the former method reveals zone inhibitions in the fixation of complement under conditions of serum excess (Kolmer, I928; Eagle, I937). Kolmer considers this zoning to be normal in specific fixations with certain sera and Eagle concurs in this view, suggesting that the main type of serum zoning is usually minimised by cold fixation. Levine (I93I), however, has noted serum zoning especially in cold fixation and believes that it indicates fixation of substances not of syphilitic origin. These differences of view may perhaps be related to the fineness of adjustment of the hæmolytic system.

Zone inhibitions under conditions of lipoid excess are I68 


\section{THE BORDET-WASSERMANN REACTION}

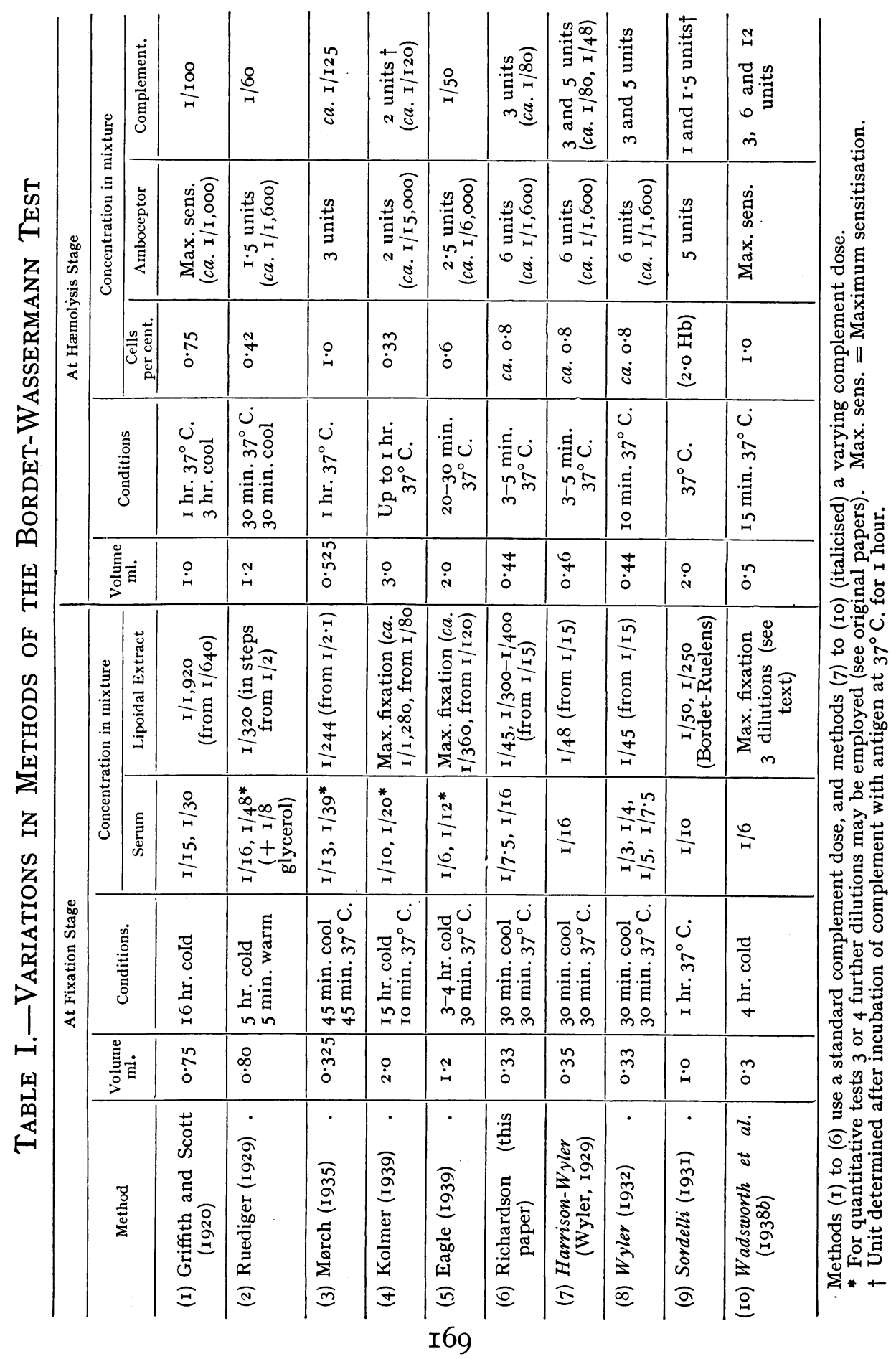




\section{BRITISH JOURNAL OF VENEREAL DISEASES}

very characteristic of the reaction (L'Esperance and Coca, I916; Ottenburg, I9I7 ; Ruediger I919; Eagle, I937; Wadsworth et al., I938a), and have led gradually to the use, first, of large serum amounts with high lipoid dilutions, and later of optimum combining proportions of serum and lipoid, determined for each lipoid extract with a minimal amount of syphilis reagin (Eagle, I936, 1939; Kolmer, I939). Lipoid has also been used in two different arbitrary strengths (Sordelli, I93I), and this variation has been extended to three strengths (Wadsworth et al., I938b), optimum for fixation of increasing amounts of complement with weakly, moderately, and strongly positive sera, respectively. The present paper explores the possibilities of using stepped combining proportions of serum and antigen with constant complement.

At the hæmolysis stage, no especial trends are noticeable. Apparently the hæmolytic system fills a straightforward rôle as indicator of fixation, and functions within somewhat wide limits. Indeed Table I shows that there has been no close agreement between either the cell concentrations or the balance of the hæmolytic components used in the various methods. Performance has been kept more or less uniform by suitable adjustment of the hæmolysis times.

\section{Theoretical Basis of the New Method}

Theoretical discussion of a test method which is as complex as the Bordet-Wassermann test cannot guarantee, by itself, the value of any modification of technique. The final proof must be the reliability of the new method under conditions of routine testing. As, however, the method reported in this paper has proved highly satisfactory under such conditions, it is of interest to outline the considerations on which it was based. These were :

(a) That the zone inhibitions observed in the BordetWassermann reaction (see above) have a general resemblance to those known to occur with authentic antigens, especially in regard to inhibition by excess antigen (Marrack, I938). Moreover, a syphilitic serum can be described adequately as an immune serum ( $c f$. Eagle, I937 ; also Dunlop and Sugden, I934), and recent work suggests that the specificity of the lipoidal antigen is determined by a chemical group (or complex) in the lipoid 


\section{THE BORDET-WASSERMANN REACTION}

surface which resembles an active group of the spirochætal antigen (Beck, I939; Eagle and Hogan, I940).

(b) That the non-specific reactions' which at present impede an increase in sensitivity may be due to the use of crude lipoidal extracts containing impurities which react with a proportion of routine sera, and that these reactions might be identified by deliberate use of zone phenomena as a means of differentiating specific from non-specific fixations.

(c) That the value of the hæmolytic system used as indicator would be enhanced by keeping its hæmolytic activity as high as possible in proportion to its fixability.

The Active Haptene ("Antigen").--Much controversy as to the specificity or otherwise of reactions with lipoidal extracts could be avoided if the active substance (hereinafter called haptene) were water-soluble and could be used in a state of chemical purity. In actual fact, however, the haptene-antibody reaction has to take place at a lipoid-water interface, and is dependent on the effective distribution or availability of haptene in the interface. What actually occurs in such reactions is not universally agreed, but the description below offers a plausible explanation of the rôle of the different components of lipoidal antigens used in syphilis serum tests, and may serve to make clear the rationale of the method described in the present paper.

It is probable that the droplets in a reactive emulsion consist of an inert bulk of lipoid coated with a film of surface-active material at the lipoid-saline interface (Eagle, I937), and that the reactivity with serum depends on the effective distribution of specific haptene in this film. It seems likely that the effectiveness of distribution is determined by the formation of rather specific, stable, molecular complexes in a mixed film (Schulmann and Rideal, r937), and will be fully effective only when each component of the reactive complex is present in the film in the right proportions and correctly oriented. It could, indeed, be considered formally that one of these components is equivalent to a simple haptene (Marrack, I938), and is converted by film formation into a complex haptene capable of participating in serum reactions (indeed, it could be considered that the haptene function results solely from a certain orientation of polar groups within the film and has no existence apart from the film).

Probably cholesterol (or other sterol) is a component of the reactive film, and is present in sufficient quantity in unfortified lipoidal extracts, as usually prepared, to permit some degree of reactivity. Without fortification, much of the lipoidal haptene remains unused in the bulk of the droplet, however, so that added cholesterol (or other bulk material, Eagle, I93I) shows its fortifying effect by increasing the 


\section{BRITISH JOURNAL OF VENEREAL DISEASES}

available surface and the formation of complex haptene within the surface film. Other fortifying effects result if the lipoidal extract contains impurities more surface-active (or forming more stable surface complexes) than the reactive haptene (or any component thereof). With a limited surface, such impurities may render much of the haptene ineffective by pushing it into the interior of the droplet, but with suitable increase of surface this haptene may again become effective by re-appearing, correctly oriented, in the surface film. Removal of all the surface-active, non-haptenic impurities may be undesirable, however, especially at high dilutions of the lipoidal extract, since they may serve to maintain a stable emulsion. Full activity of the emulsion may be displayed only if a correct balance is attained in the interface between several unknown bodies, and one of the immediate problems of research in this field is the isolation and identification of these.

In such circumstances, differences of technique may greatly affect the distribution attained on a limited surface, and conditions governing the formation of the original emulsion will be vital to its subsequent performance (Griffith and Scott, I920, p. 6I). Lipoidal emulsions having identical haptene concentrations may thus have quite different properties (Eagle, I937). This will be especially so if the extract contains specific haptenes and contaminating haptenes both competing for the available surface, when it may be found that differences of technique alter both sensitivity and specificity simultaneously. For these reasons, actual concentrations of haptene are of little significance in discussion, and in what follows the term "haptene strength " will be used,* implying the amount of effectively distributed haptene available for combination with antibody. It will be seen that the important rôle of physical factors in serum reactions for syphilis may well be a consequence, rather than a contradiction, of the suggested specific nature of the lipoidal haptene.

As to the chemical nature of the haptene, it will be obvious that both the isolation of the active lipoid and the proof of its reactivity are matters of some complexity. In general, the active lipoid resembles a phospholipoid, and it is found in certain lecithin fractions (Browning and McKenzie, I924). Nevertheless, it seems that purified lecithin and cephalin do not contain it

* Both Eagle (1937) and Kolmer (1939) titrate their extract to discover its optimum concentration for use, but neither worker insists that it shall be diluted for the test by the same technique as used for the titration. The possibility exists, therefore, that optimum haptene strength is not always in use in these tests. 


\section{THE BORDET-WASSERMANN REACTION}

(Wadsworth et al., I934). A considerable purification of the active material has been recorded by Ö. Fischer (I937).

The Fixation Stage.-At the third Laboratory Conference of the League of Nations Health Organisation (I93I), the Wassermann methods which gave, with sera, the highest sensitivity compatible with specificity of positive reactions were the Harrison-Wyler (I929) and the Sordelli (I93I). These methods differed notably, however, in respect of weak fixations. The Harrison-Wyler gave doubtful results with I3 per cent. of the 623 syphilitic sera and 8 per cent. of the 304 non-syphilitic sera, as compared with percentages of 6 and $0 \cdot 7$, respectively, with the Sordelli method. The low incidence of nonspecific partial fixations with the Sordelli method draws attention to its peculiarity in using two strengths of lipoidal emulsion. These were used not only with two strengths of complement to measure reaction strength but also with constant complement under conditions which should have revealed zone phenomena. This circumstance, though not specifically commented on by Sordelli, probably accounts for the rarity of non-specific fixations recorded by him. Wyler (I932) later improved on the sensitivity of the Harrison-Wyler method, revealed at the Conference, by increasing the amount of serum, since this was found to be more effective than changing the lipoid strength. This increase was accompanied by a reduction in number of non-specific partial fixations (from $9 \cdot 3$ to $2 \cdot 6$ per cent.), which was attributed to the longer hæmolysis time necessitated by the altered technique.

In the new method described below the useful features of Sordelli's and Wyler's methods are combined in a deliberate attempt to use zone phenomena as a guide to specificity. The ability to distinguish between specific and non-specific fixations in this way depends on the presence of an abundant amount of specific haptene (or of its components) in the lipoidal extract. Optimum combining proportions with the customary serum dose can then be attained only by considerable dilution of the extract, and at such dilutions the strength of any contaminating haptene or haptenes is normally much too low to fix the full dose of complement. With such partial fixations, differentiation of specific from non-specific 


\section{BRITISH JOURNAL OF VENEREAL DISEASES}

effects can be promptly made if the contrasted effects are noted of using (in presence of constant complement) the lipoidal emulsion both in proportions giving excess of specific haptene, as occurs with the customary dilution of extract, and in optimum combining proportions, as with higher dilution of extract. A specific reaction which is partially suppressed, by zoning, with the customary dilution of extract, should be enhanced under conditions of optimum proportions ; a non-specific reaction which is partial with the customary dilution should, on the other hand, be weakened by further dilution. Thus, provided that the contaminating haptene is never able to fix the whole complement dose with non-syphilitic sera at the higher dilution of extract, a reliable guide to specificity is obtained.

In the experiments to follow, a constant complement dose has been linked with a sixfold to tenfold decrease (estimated by titration) in lipoid strength, and this has been coupled with a twofold increase of serum dose to provide an estimate of strength of reaction.

The Hamolysis Stage.-It is mainly at the fixation stage that the new method differs from the Harrison-Wyler and Wyler methods (I929, I932). Study of the effects of this difference will be asssisted, therefore, by having no difference in hæmolytic reagents. This has been done in the comparison series of tests reported in this paper, but two slight changes are embodied in the conditions under which hæmolysis occurs in the new test. The first of these follows from the reduced amount of alcoholic extract, which lessens the extent of complement deterioration during fixation. The second follows from the well-known power of certain human sera to enhance hæmolytic activity. It was found that this property extended, in part, to the ash of these sera, and that magnesium (Kellogg and Wells, I926), cobalt, or nickel salts were probably responsible. It seemed wise to ensure the presence in all tests of sufficient catalytic salt to give the increased hæmolytic activity, and to this end a magnesium salt was added (Kolmer, I928). This addition has not affected fixability except for a possible slight enhancement.

In effect, the hæmolytic dose of complement employed in the new method is thus somewhat greater than the three units indicated in Table I (though its fixability is little altered). It was nevertheless possible to set up and 


\section{THE BORDET-WASSERMANN REACTION}

read tests by the new method and the Harrison-Wyler method simultaneously. In these comparisons, the new method showed, by reason of the more active hæmolysis, a clarity and preciseness in reading that was very pleasing.

\section{Technical Details}

The technique was a composite one designed to allow tests by the new method to be run in parallel with tests by the Harrison-Wyler method (Wyler, I929) under closely similar conditions. Since the result of the comparison was very favourable, a procedure more suited to routine testing by the new method is being developed.

The composite test was set up in five tubes which were filled as shown in Table II. It will be seen that Row 5 is the 3-unit serum control of the Harrison-Wyler and Row 4 the serum control of the new method. Rows 3 and 2 are the test rows of the former and Rows 2 and $I$ the test rows of the new method. Row 2 is thus used in both methods, and it is necessary to point out the slight differences between it and Row I, apart from differences in serum and lipoid dilution. In Row 2 the volume per tube is 5 per cent. greater than in Row I, and there is no magnesium in it, both factors tending to make any hæmolysis slightly slower than in Row I. The difference cannot affect anything but the incidence of ++ and + readings by the new method. Conclusions as to specificity and overall sensitivity are not altered.

The general technique followed that described by Wyler (I929) as far as possible, and his paper should be consulted for greater detail.

Saline.-This was a sterile, 0.85 per cent. solution of pure sodium chloride in distilled water.

Diluted Serum.-The sera were inactivated for thirty minutes at $55^{\circ}$ and diluted with saline in the amounts shown in Table II. For Rows I and 4 a solution of magnesium salt was added. The magnesium concentration of normal serum varies from $M / 800$ to $M / \mathrm{I}, 200$, and the amount added was originally $1 / 5$ volume of $M / 400$ magnesium chloride. Later, the catalytic activity of magnesium was found to extend over concentrations up to $M / 20$ ( $M / 400$ during hæmolysis), and the amount was changed to $M / 50$ magnesium glycerophosphate, since this salt had a $p \mathrm{H}$ of $7 \cdot 6$ and appreciable buffering power. 


\section{BRITISH JOURNAL OF VENEREAL DISEASES}

\section{Table II.-Details of Composite Test}

\begin{tabular}{|c|c|c|c|c|c|c|c|c|}
\hline \multirow{2}{*}{ Row } & \multirow{2}{*}{ Serum } & \multirow{2}{*}{ Saline } & \multirow{2}{*}{$\begin{array}{c}\mathrm{Mg} . \\
\text { Solution } \\
\text { (see text) }\end{array}$} & \multicolumn{2}{|c|}{ Comflement containing } & \multicolumn{2}{|c|}{ Lipoid Emulsion } & \multirow{2}{*}{$\begin{array}{l}\text { Sensi- } \\
\text { tised } \\
\text { Cells }\end{array}$} \\
\hline & & & & 3 units & 5 units & Standard & Diluted & \\
\hline 5 & $\begin{array}{l}\text { vol. } \\
\text { I } / 5\end{array}$ & $\begin{array}{c}\text { vol. } \\
2\end{array}$ & vol. & $\begin{array}{c}\text { vol. } \\
\text { I }\end{array}$ & vol. & vol. & vol: & $\begin{array}{c}\text { vol. } \\
\text { I }\end{array}$ \\
\hline 4 & $2 / 5$ & I $2 / 5$ & $I / 5$ & $\mathbf{I}$ & - & - & 一 & I \\
\hline 3 & $\mathrm{I} / 5$ & I & - & - & I & I & - & I \\
\hline 2 & $\mathrm{I} / 5$ & I & - & I & - & I & 一 & I \\
\hline I & $2 / 5$ & $2 / 5$ & $1 / 5$ & I & - & - & I & I \\
\hline
\end{tabular}

$\mathrm{I}$ vol. = I drop from the appropriate large dropper ( $0 . \mathrm{I} \mathrm{I} \mathrm{ml}$.), and I $/ 5 \mathrm{vol} .=\mathrm{I}$ drop from the hand dropper (0.022 ml.) as described by Wyler (1929).

It has since been noticed that the occasions on which the new method gave non-specific partial fixations all occurred at this time, and it seems advisable to return to the use of the chloride (I/5 volume of, say, $M / 250=$ $0 \cdot I$ per cent. of $\left.\mathrm{MgCl}_{2} \cdot 6 \mathrm{H}_{2} \mathrm{O}\right)$.

Complement.-This was a pooled specimen of serum from three healthy male guinea-pigs. It was preserved by freezing solid, and used within three or four days. The unit was that complement dilution of which I volume would almost, though not quite, completely hæmolyse I volume of sensitised cells in an overall volume of 4 volumes. Sensitivity to antigen was observed by measuring the change in magnitude of the unit with I volume of standard emulsion present, when the necessary complement dose should not be more than doubled.

Lipoid Emulsion.-This was the McIntosh and Fildes emulsion adopted in the Harrison-Wyler method. It is made from an alcoholic extract of healthy human heart prepared with 9 volumes of absolute alcohol at $37^{\circ}$ for twenty-four hours. The standard emulsion is prepared by pouring 70 volumes of saline on to a mixture of 3 volumes of extract with 2 volumes of I per cent. cholesterol, and mixing well (giving a $\mathrm{I}$ in $\mathrm{I} 5$ dilution of alcoholic extract containing 0.4 per cent. cholesterol). Control tests were made on the hæmolytic and anticomplementary properties of this emulsion and on its sensitivity.

The emulsion was also used in greater dilution (see Row I, Table II). The aim in this was to weaken the nonspecific fixation as far as was consistent with the preservation of sufficient haptene in the extract to give complete absence of lysis with strongly reacting syphilitic

$$
\text { I76 }
$$




\section{THE BORDET-WASSERMANN REACTION}

sera and something near optimum fixation with weakly reacting syphilitic sera. The dilution was arrived at by a titration of haptene strength, and was arbitrarily taken as the highest dilution of standard emulsion in saline which, under conditions similar to Row I, would completely fix 4 units of complement with several different strongly positive sera. The end-point was noted after 5 minutes incubation at $37^{\circ}$, and gave the standard haptene strength for use with 3 units of complement in tests using that extract. This was about the lowest haptene strength which could be used without weakening certain specific fixations as the result of haptene insufficiency, and its ability to give full fixation of the standard complement dose with a positive control serum must be checked each test day. By using a titration method based on that of Eagle (I936) it was also shown that this haptene strength is about the optimum for use with weakly reacting syphilitic sera. The range of dilution of the standard emulsion has varied from $\mathrm{I}$ in 6 to $\mathrm{I}$ in ro (i.e., I in 90 to $I$ in 150 of the standard extract, diluted in two stages), and needs confirming only very occasionally in the life of an extract. Since the dilution is always carried out on a pre-formed lipoidal emulsion, the exact change of haptene strength is reproducible from day to day.

Sensitised Cells.-These were sheep cells adjusted colorimetrically to a standard hæmoglobin content which represents approximately 3 per cent. cells by volume. The cells were sensitised for fifteen minutes at $37^{\circ}$ with 6 units of rabbit $v$. sheep amboceptor, the unit being measured infrequently as described by Wyler (I929).

Procedure.-The reagents were added to the tubes in the sequence : dilute serum (diluted in tube with addition of magnesium if indicated), dilute complement, lipoid emulsion, and sensitised cells, the Donald dropping technique being used. The more dilute lipoid emulsion was added from the saline $(0.76 \mathrm{~cm}$.) dropper. Controls were included each test day on the fragility of the cells, the native hæmolysin of the serum used for complement, the effect of the lipoid emulsion and of each serum on the complement, and the fixability of known positive and negative sera. Fixation of the first three reagents proceeded for thirty minutes at room temperature, followed by thirty minutes in the water bath at $37^{\circ}$. After addition of the sensitised cells, the tubes were 


\section{BRITISH JOURNAL OF VENEREAL DISEASES}

incubated for three to five minutes in the water bath, until the lipoid controls, most of the serum controls, and most of the negative sera, including the known negative, showed complete hæmolysis.

Readings.-During hæmolysis, the tubes were watched closely, removed from the bath when ready, read quickly, and interpreted as indicated in Table III. The degrees

Table III.-Method of Reading Results

\begin{tabular}{|c|c|c|c|c|}
\hline \multicolumn{3}{|c|}{ Extent of Hæmolysis } & \multicolumn{2}{|c|}{ Interpretatic $n$} \\
\hline Tube I & Tube 2 & Tube 3 & New Method & $\begin{array}{l}\text { Harrison-Wyler } \\
\text { Method }\end{array}$ \\
\hline $\begin{array}{c}\text { None } \\
\text { None } \\
\text { None } \\
\text { Incomplete } \\
\text { Some } \\
\text { Some } \\
\text { Complete } \\
\text { Complete }\end{array}$ & $\begin{array}{c}\text { None } \\
\text { None } \\
\text { Incomplete } \\
\text { Complete } \\
\text { None } \\
\text { None } \\
\text { None } \\
\text { Incomplete }\end{array}$ & $\begin{array}{c}\text { None } \\
\text { Some } \\
\text { Complete } \\
\text { Complete } \\
\text { None } \\
\text { Some } \\
\text { Some } \\
\text { Complete }\end{array}$ & $\begin{array}{l}++ \\
++ \\
+ \\
\pm \\
\pm \\
\pm \\
\pm\end{array}$ & $\begin{array}{l}++ \\
+ \\
\pm \\
+ \\
+ \\
+ \\
+ \\
\pm\end{array}$ \\
\hline
\end{tabular}

Readings intermediate between \pm and - (i.e., where hæmolysis is barely complete) may be recorded as \pm , but are considered negative for clinical purposes.

of lysis noted in the Table are purposely left vague, since the proper standards must be discovered by trial.

\section{RESULTS}

Comparison of Routine Methods. A comparison series of tests was done with the Harrison-Wyler method (Wyler, I929) and the new method on I,56I consecutive sera (omitting three anticomplementary sera) kindly provided by the V.D. Clinic at St. Thomas's Hospital. No clinical details were known at the time of testing. When these details were received later, it was noted that some cases had provided more than one specimen included in the totals, these specimens representing successive stages in treatment. The number of cases has therefore been noted as well as the number of sera. These details and the results of the comparison are shown in Table IV. This unselected group of sera is seen to include only 20 from untreated cases and 525 from cases in various stages of treatment for syphilis. In 18 there were histories of syphilis for which positive clinical evidence was lacking, and in 5 there were old histories of sores, 


\section{THE BORDET-WASSERMANN REACTION}

possibly syphilitic. The remaining 993 were either cases of gonorrhoea or soft chancre, or had attended the clinic under some suspicion of venereal disease. Of the 525

TABLE IV.-COMPARISON BETWEen THE HARRISON-WYLER AND the NeW Method on I,56I Sera

\begin{tabular}{|c|c|c|c|c|c|c|c|c|c|c|c|c|c|c|}
\hline & & \multicolumn{2}{|c|}{$\begin{array}{l}\text { Untreated } \\
\text { Syphilis }\end{array}$} & \multicolumn{5}{|c|}{$\begin{array}{l}\text { Treatcd } \\
\text { Syphilis }\end{array}$} & \multicolumn{3}{|c|}{$\begin{array}{l}\text { History of } \\
\text { Syphilis or of } \\
\text { Sore }\end{array}$} & \multicolumn{3}{|c|}{ Non-syphilis } \\
\hline \multirow[t]{3}{*}{$\begin{array}{l}\text { No. of sera } \\
\text { No. of cases }\end{array}$} & \multirow[t]{3}{*}{ : } & \multicolumn{2}{|c|}{$\begin{array}{l}20 \\
20\end{array}$} & \multicolumn{5}{|c|}{$\begin{array}{l}525 \\
374\end{array}$} & \multicolumn{3}{|c|}{$\begin{array}{l}23 \\
21\end{array}$} & \multicolumn{3}{|c|}{$\begin{array}{l}993 \\
847\end{array}$} \\
\hline & & \multirow[t]{2}{*}{++} & \multirow[t]{2}{*}{-} & \multicolumn{3}{|c|}{ Positives } & \multirow[t]{2}{*}{ \pm} & \multirow[t]{2}{*}{-} & \multirow[t]{2}{*}{+} & \multirow[t]{2}{*}{ \pm} & \multirow[t]{2}{*}{-} & \multirow[t]{2}{*}{+} & \multirow[t]{2}{*}{ \pm} & \multirow[t]{2}{*}{-} \\
\hline & & & & ++ & + & Total & & & & & & & & \\
\hline \multicolumn{2}{|c|}{$\begin{array}{l}\text { Harrison-Wyler method } \\
\text { New method }\end{array}$} & $\begin{array}{l}17 \\
17\end{array}$ & $\begin{array}{l}3 \\
3\end{array}$ & $\begin{array}{r}71 \\
125\end{array}$ & $\begin{array}{l}53 \\
79\end{array}$ & $\begin{array}{l}124 \\
204\end{array}$ & $\begin{array}{l}87 \\
97\end{array}$ & $\begin{array}{l}314 \\
224\end{array}$ & 4 & $\begin{array}{r}6 \\
13\end{array}$ & $\begin{array}{r}17 \\
6\end{array}$ & $3^{*}$ & $\begin{array}{r}2.1 \\
6\end{array}$ & $\begin{array}{l}966 \\
987\end{array}$ \\
\hline
\end{tabular}

* From I case (see text).

sera from treated cases of syphilis, 40I gave weak reactions or were negative by the Harrison-Wyler test, and thus fall in the category for which the new method was especially designed.

The Table illustrates clearly the advantage of the new method over the Harrison-Wyler in respect of both sensitivity and specificity. As regards sensitivity, the percentage of positive reactions in the treated syphilis series was 23.6 by the Harrison-Wyler and 38.8 by the new method. In the series "History of Syphilis or of Sore," the 4 positive reactions by the new method might, of course, have been non-specific, but the absence of any similar reaction in the non-syphilitic series testifies to the contrary. With regard to the 27 partial and complete reactions in the non-syphilitic series with the HarrisonWyler method, it should be noted that they were from 22 patients of whom I provided 3 specimens giving \pm reactions, and another, 4 specimens, which gave I \pm and the $3+$ reactions (all with the same heart extract). Specimens from this patient were tested by seven other pathologists as part of a scheme of comparison tests. Two reported + ; three, \pm ; one, + and \pm on different occasions; and one, - . All seven specimens from these 2 cases gave negative reactions by the new method and by the Kahn test. The 6 sera giving partial reactions by the new method came from 4 other cases. Three of these 6 partial reactions (from 3 cases) occurred with one batch of complement, and all occurred while $M / 50$ magnesium 
glycerophosphate was being used, though the precise significance of this is not known. There is some prospect that suitable modification may give even greater specificity.

For further information, sera giving weak or anomalous reactions were re-tested by Wyler's method (I932) using the three-fold increase (3/5 volume) of serum amount. Results by the three methods, on this selected group of sera with non-syphilitic controls, are compared in Table V.

TABle V.-Comparison BetWeen Three Wassermann Methods on Selected Sera

\begin{tabular}{|c|c|c|c|c|c|c|c|c|c|c|c|c|c|c|}
\hline \multirow{3}{*}{$\frac{\text { No. of sera }}{\text { Method }}$} & \multicolumn{5}{|c|}{ Treated Syphilis } & \multicolumn{5}{|c|}{$\begin{array}{l}\text { History of Syphilis } \\
\text { or of Sore }\end{array}$} & \multicolumn{4}{|c|}{ Non-syphilis } \\
\hline & \multicolumn{5}{|c|}{181} & \multicolumn{5}{|c|}{ I9 } & \multicolumn{4}{|c|}{81} \\
\hline & ++ & + & \pm & \pm & - & ++ & + & \pm & \pm & - & + & \pm & \pm & - \\
\hline $\begin{array}{l}\text { Harrison-Wyler } \\
\text { Wyler } \\
\text { New method }\end{array}$ & 23 & $\begin{array}{l}37 \\
55\end{array}$ & $\begin{array}{l}58 \\
47 \\
87\end{array}$ & $\begin{array}{l}21 \\
15\end{array}$ & $\begin{array}{r}123 \\
53 \\
24\end{array}$ & 2 & $\begin{array}{l}3 \\
3\end{array}$ & $\begin{array}{r}4 \\
7 \\
13\end{array}$ & $\begin{array}{l}3 \\
2\end{array}$ & $\begin{array}{r}15 \\
4 \\
1\end{array}$ & $3^{*}$ & $\begin{array}{r}21 \\
8 \\
6\end{array}$ & $\begin{array}{r}\text { I I } \\
2\end{array}$ & $\begin{array}{l}57 \\
62 \\
73\end{array}$ \\
\hline
\end{tabular}

* From I case (see text).

Wyler's main claim for increasing the serum amount was that it " enables a definite answer of positive or negative to be given " without loss of specificity, "in a significant proportion of cases" which would otherwise be left in doubt. This is supported by Table V, which shows $60++$ and + reactions with sera from treated syphilis cases tested by the Wyler method, compared with 55 by the new one. The new method has the advantage, however, in the significance of the \pm reactions, since these occurred in a much higher proportion of the treated syphilitic sera and yet a lower proportion of the nonsyphilitic sera tested by the new method than by either the Wyler or the Harrison-Wyler method. The same argument applies also to the \pm results, and gives promise of some success in increasing further the sensitivity of the new method.

A full opportunity to compare the new method thoroughly with flocculation tests has not occurred, but it may be mentioned that in the series reported in Table IV the 525 treated cases of syphilis gave 245 wholly negative readings by the Kahn test (I928).

Non-specific Partial Fixations in the Harrison-Wyler Method.-The theoretical interpretation suggested for I80 


\section{THE BORDET-WASSERMANN REACTION}

these fixations presupposes a random distribution of special kinds of sera throughout the population. The incidence of such fixations should therefore be of the same order among syphilitic as among non-syphilitic persons. Among 847 non-syphilitic persons there were 22 (providing 27 serum specimens) whose sera reacted in the Harrison-Wyler but not in the new method or the Kahn test, corresponding to an incidence of 2.6 per cent. Among syphilitic cases this type of result will of course only be noted in the absence of syphilitic reagin in the serum. Among I66 such cases (224 sera) giving no reaction by the new method, 6 cases (Io sera) reacted with the Harrison-Wyler method though negative with the Kahn test, giving an incidence of $3 \cdot 6$ per cent. From the standpoint of permanence, this type of reaction showed itself in 4 specimens from a non-syphilitic case over a period of 6 months, and in 5 specimens from a treated syphilis case over a period of 8 months. Thus the supposition that certain partial fixations are due to a lasting serum condition in a small proportion of the population is not without support.

Experiments with Individual Sera.-These main conclusions derived from a large group of sera may be supplemented by conclusions resulting from individual tests. The modifications which are applied in combination in the new method were also applied singly to representative sera to reveal the main effect of each modification on each type of serum. The results are shown in Table VI. Confirmation is thus obtained that increase in specific reactions is mainly due to the increase of serum amount, though decrease in lipoid strength and addition of magnesium contribute to the detection of very weak, specific reactions. The decrease in non-specific reactions is mainly due to the decrease in lipoid strength as suggested in the theoretical discussion. The nature of the non-specific partial fixation occurring with the new method is not yet clear. The one example examined showed that this fixation is strengthened by increase of serum, reduced by decrease of lipoid strength, and raised again by the presence of magnesium glycerophosphate.

Results with Anomalous Sera.-Fifty-six sera, selected on account of anomalous results by Dr. P. Krag of the Statens Serum Institut, Copenhagen, were tested in I $8 \mathrm{I}$ 
BRITISH JOURNAL OF VENEREAL DISEASES

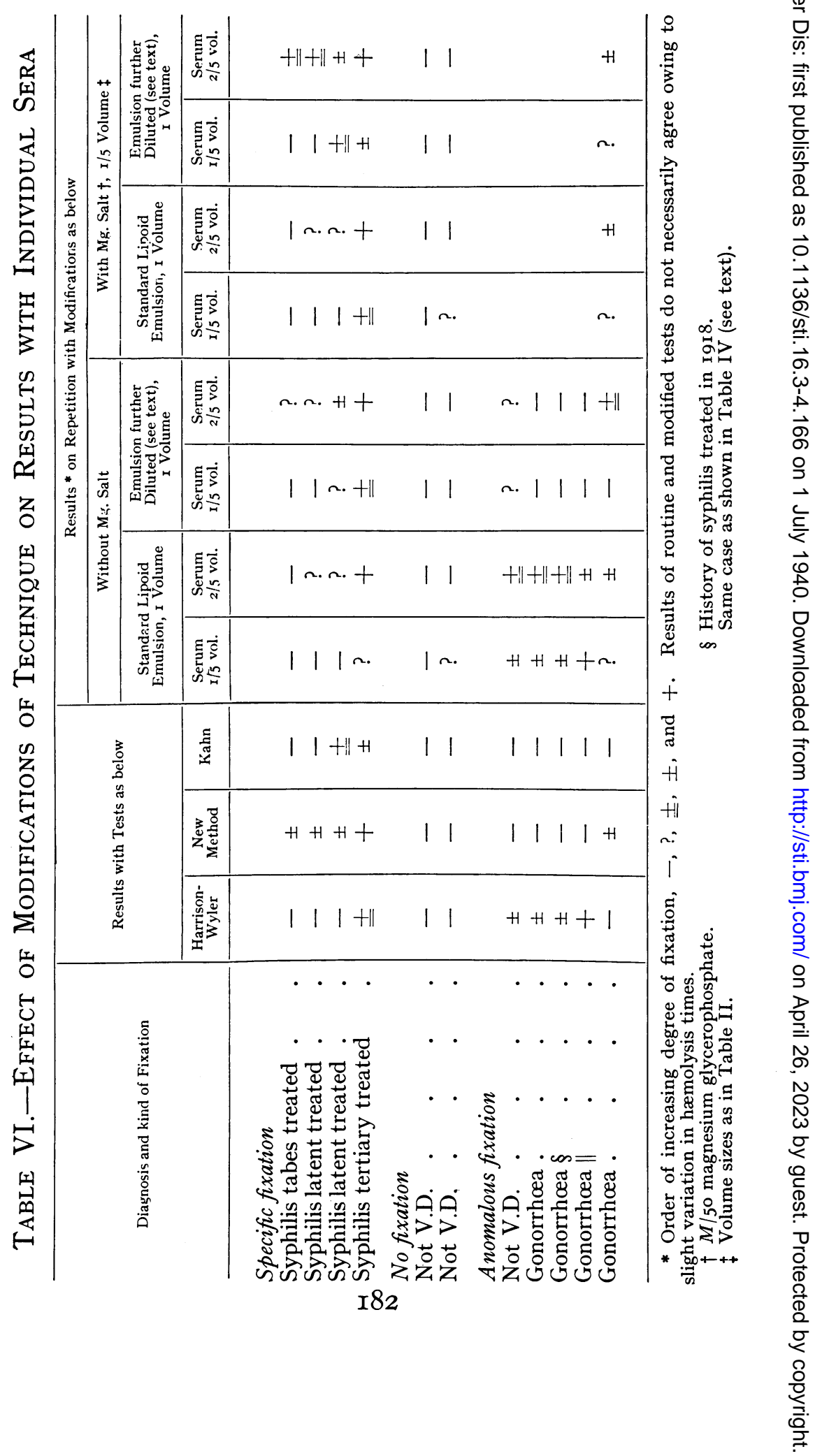




\section{THE BORDET-WASSERMANN REACTION}

Copenhagen by the Mørch complement-fixation method, the Kahn and presumptive Kahn tests, the Müller Ballungsreaktion, and the Meinicke Klärungsreaktion, and in London by the Harrison-Wyler, Wyler, and new complement-fixation methods, and the Kahn test. Unfortunately, the final outcome of this work was interrupted by international events, and detailed results cannot be published. A comparison on 4I sera showed broadly, however, that the new method was equalled in specificity by only one other method, and in sensitivity (inclusive of \pm results) by no other method. Excluding \pm results, it was excelled in sensitivity by the Wyler method only. In this work, the value of the use of two antigen strengths to indicate the nature of anomalous fixations was especially noteworthy.

\section{DiscUSSION}

Specificity of the Wassermann test probably depends both on a correct adjustment of hæmolysis times to suit the balance of the hæmolytic system, and on the absence of reactive concentrations of contaminants in the lipoidal extract. On the latter point, most of the recent methods have adopted a partial purification of the lipoid and its use at high dilution (Kolmer, I928 ; Mørch, I935 ; Eagle, I937; Wadsworth et al., I938b). Since it is doubtful to - what extent a simple fractionation can remove sufficient contaminating material to influence specificity, the technique described in this paper may be of use even with partially purified lipoid preparations. In tests with partially purified lipoid by the Eagle method, Vogelsang (I940, Table 67) has reported 0.9 per cent. of fixations (full or partial) among I,606 non-syphilitic sera. If these fixations could be reduced in any proportion approaching the four-fold reduction recorded in this paper, a close approach to absolute specificity would be attained.

The merits of cold, as compared with room temperature (cool) fixation have not yet been investigated with the new method. Vogelsang (I940, Tables I9 and 20) has reported 0.75 per cent. of non-specific fixations (full or partial) with 4,246 non-syphilitic sera tested by a warm fixation method corresponding otherwise with the Eagle technique, as against $I \cdot 0$ per cent. by the true Eagle I83 


\section{BRITISH JOURNAL OF VENEREAL DISEASES}

technique. If such fixations could be eliminated by using the method here described, full use could be made of the increase of sensitivity resulting from cold fixation.

\section{SUMMARY}

The specificity of the Wassermann reaction can be notably improved by using two strengths of lipoidal emulsion as was done by Sordelli (I93I), in combination with two strengths of serum. The results are interpreted as if subject to the zone inhibitions of an authentic immune reaction, and the nature of the inhibition is used as a guide to specificity. For obvious reasons, the complement dose must be kept constant.

By adapting the Harrison-Wyler method (Wyler, I929) accordingly, a degree of sensitivity comparing with Wyler's modification (I932) has been maintained, and linked with a marked improvement in the detection and diagnostic significance of partial fixations (doubtful reactions).

The author is very grateful to Col. L. W. Harrison for his interest and encouragement in this work, and to Dr. T. Anwyl Davies, St. Thomas's Hospital, and Dr. P. Krag, Statens Serum Institut, Copenhagen, for the supply of serum specimens.

\section{REFERENCES}

BECK, A. (I939) J. Hygiene, 39, 298.

Boerner, F., and Lukens, M. (I937) Amer. J. Clin. Path., \%, 33.

Browning, C. H., and McKenzIE, Ivy (I924) " Recent Methods in the Diagnosis and Treatment of Syphilis." (Constable London.)

Dunlop, E. M., and Sugden, S. (I934) J. Path. Bact., 39, I49.

EAGLE, H. (I93I) J. Exp. Med., 53, 605.

EAGLe, H. (I936) J. Lab. Clin. Med., 22, 300.

EAGLE, H. (I937) "The Laboratory Diagnosis of Syphilis." (C. V. Mosby, St. Louis.)

EAGLE, H. (I939) V. Dis. Inform. Supplement, No. 9, I59. (U.S. Govt. Printing Office, Washington.)

EAgLe, H., and Hogan, R. B. (I940) J. Exp. Med., ri, 2 I5.

FISCHER, Ö. (I937) $Z$. Immforsch., 90, 348.

GAEHTGENS, W. (I929) Z. Immforsch., 63, 398.

Gaehtgens, W. (I932) $Z$. Immforsch., '73, 527.

Griffith, F., and ScotT, W. M. (I920) Rep. on Public Health and Med. Subj., No. I, 7. (H.M. Stationery Office, London.)

KaHN, R. L. (I928) “The Kahn Test." (Williams and Wilkins, Baltimore.) 


\section{THE BORDET-WASSERMANN REACTION}

KellogG, W. H., and Wells, L. Amy (I926) J. Lab. Clin. Med., 12, I53. Kolmer, J. A. (I928) "Serum Diagnosis by Complement Fixation." (Lea and Febiger, Philadelphia.)

Kolmer, J. A. (I939) V. Dis. Inform. Supplement, No. 9, I7 and 207. (U.S. Govt. Printing Office, Washington.)

League of Nations Health Organisation (ig29) Series $L$. of $N$.

Publications in Health, I929, iii, 3 (No. C.H. 726). (Allen and Unwin, London.)

League of Nations Health Organisation (I93I) Series $L$. of $N$. Publications in Health, I93I, iii, 4 (No. C.H. 968). (Allen and Unwin, London.)

L'Esperance, Elise S., and Coca, A. F. (Igi6) J. Immunol., 1, I29. Levine, B. S. (I93i) J. Infect. Dis., 48, r89.

Marrack, J. R. (1938) Med. Res. Council Spec. Rep. Series, No. 230. (H.M. Stationery Office, London.)

Medical Research Committee (I92I) Med. Res. Council Spec. Rep. Series, No. I4. (H.M. Stationery Office, London.)

MøRCH, J. R. (I935) Ugeskr. f. Laeger, 97, 392.

OTTENBURG, R. (I9I7) J. Immunol., 2, 47.

Ruediger, E. H. (I9I9) J. Infect. Dis., 25, 224.

Ruediger, E. H. (I929) J. Lab. Clin. Med., 15, 272.

Schulmann, J. H., and Rideal, E. K. (I937) Proc. Roy. Soc., B, 122, 29.

Sordelli, A. (I93I) Series L. of N. Publications in Health, I93I, iii, 4 (No. C.H. 968), I23. (Allen and Unwin, London.)

Vogelsang, T. M. (I940) "Séro-diagnostic de la Syphilis." (J. W. Eides Boktrykkeri, Bergen.)

Wadsworth, A., Maltaner, Eliz., and Maltaner, F. (I934) $J$. Immunol., 26, 25.

Wadsworth, A., Maltaner, F., and Maltaner, Eliz. (I938a) J. Immunol., 35, I05.

Wadsworth, A., Maltaner, F., and Maltaner, Eliz. (I938b) J. Immunol., 35, 217.

Wyler, E. J. (I929) Med. Res. Council Spec. Rep. Series, No. I29. (H.M. Stationery Office, London.)

Wyler, E. J. (1932) Rep. on Public Health and Med. Subj., No. 67. (H.M. Stationery Office, London.) 